\title{
Chromatin Antibody Measurement
}

National Cancer Institute

\section{Source}

National Cancer Institute. Chromatin Antibody Measurement. NCI Thesaurus. Code C147318.

The determination of the amount of chromatin antibody present in a sample. 